\title{
SALES FORCE AND INTELLIGENCE STRATEGIC IN SMES PERFORMANCE: CASE STUDY OF BATIK'S ENTERPRISES IN BRINGHARJO YOGYAKARTA
}

\author{
Ahmad Johan ${ }^{1)}$, Dessy Isfianadewi'²), Tezza Adriansyah Anwar ${ }^{3)}$ \\ ${ }^{1)}$ Magister of Management Universitas Islam Indonesia, Yogyakarta \\ ${ }^{2)}$ Departement of Management Universitas Islam Indonesia, Yogyakarta \\ ${ }^{3)}$ Business and Management Faculty, Widyatama University, Bandung
}

Corresponding author: ahmadjohan9191@gmail.com

\begin{abstract}
The purpose of this study is to investigate how small \& medium scale companies in managing Sales Forces owned \& strategic intelligence in obtaining information amid complex competition with all its limitations. The context of Small \& Medium Enterprises (SMEs). Sales Force is the key to the strength of organizational success. Frequent interaction with consumers \& competitors brings up a dynamic concept which is defined as routine regulating other routines, that is, besides its function as a salesperson, it is tasked to gather the information. Activity in searching information through intelligence from sales is called activity intelligence. External information obtained by the company through the Sales Force will lead to strategic planning so as to encourage organization performance to be able to flexibly adjust current business trends. This study used a case study to answer the research questions. Four enterprises were chosen as cases in this study. The result shows that the Sales Force's role will have an impact on organization performance, but organizations that implement activity intelligence through sales forces will be far more flexible \& active in adjusting the business before the competition starts. In addition, this study also found strong linkages for organizations that grow through Sales Force \& Activity Strategic Intelligence in terms of improving organization Performance.
\end{abstract}

Keywords: Small \& Medium Entreprises (SMEs), Sales Force, Intelligence Strategies, Enterpises Performance

\section{Introduction}

The important point in developing effective strategic planning is to scan the environment to find opportunities and threats (Anshof, 1975). In strategic management, the flow of information in the external environment is very important for the sustainability of the company in order to continue to survive crying out the business (Thitart, 1981). At present, the companies are required to continue to update the information in order to be able to compete (Javalgi et al, 2005; Joly, 2008). In the context of small and medium enterprises (SMEs), the role of the sales force is the main capital that should be managed to control the flow of information (Joly, 2008). Therefore the role of it (sales force) that can represent the company when dealing with consumers and competitors (Thitart, 1981; Anderson, 2012). As a strategic key to the success of a sales force the company is also able to determine the company's performance (Douglas, 1990; Javalgi, 2005).

In facing very high competition pressures especially that is seen in the traditional market with various aspects, Beringharjo Yogyakarta market is a market whose location is made into an area with homogeneous product sellers. For some SMEs in the market, the function of the sales force is not only as sellers who only sell products, but also their proximity to consumers makes sales force as collecting of information (Thitart, 1981). In this situation, a concept emerged which was defined as the routine of managing other routines, the main role of the sales force was as a seller, but another important role was to become espionage in seeking information (Verona, 2013).

Keegan (1974) states that the sales force will be a source of information that is very dependent on the characteristics possessed because not all sales are able to contribute to the search for information in the external environment (Keegan, 1974). In other words, the main key that determines the ability to improve company performance is in the sales skills possessed (Churchill et al, 2000). The better the sales force capability that a company has in absorbing information, the better the company's performance in facing 
competition. This activity in searching for information is called as good as strategic intelligence activity (McDowell, 2009).

History of intelligence activity is often used in military activities to find the information related to an opponent or enemy in order to formulate a competitive strategy or even be used as a problem solver in the organization (McDowell, 2009). Nevertheless, studies have noted that intelligence activity has attracted many managers' attention to be applied as competitive strategies, understanding consumer behavior, planning strategies by looking at current trends and detecting opportunities, and threats (Natalia, 2013; Sheen, 2017). For small and medium enterprises (SMEs) problems arise mainly in information related to products, distributors, and suppliers. Strategic intelligence can be used to overcome this limitation as a tool that can be used by companies with their own resources. But it is different for companies that only use sales forces as salespeople without strategic intelligence, of course, they will be far behind their competitors.

Although the study noted that the role of the sales force was able to improve company performance, it would be better if the company also included strategic intelligence as a supporter of business operations. Therefore sales force and strategic intelligence are important to be applied in the scope of small and medium enterprises (SMEs) to improve performance so that the company is quick in responding to changes.

The problems that would be discussed in this study are: Does better managing sales force and intelligence strategic activity lead to an increase enterpises performance?; How the manager could lead sales force capable of integrating strategic intelligence?

\section{Literature Reviews}

\section{Sales Force}

In the company, sales force is the spearhead for achieving sales success. Its role represents the company to be able to interact with consumers. Besides conducting sales activities, the sales force also acts as a strategic approach to obtain external information (Li \& Nicholic, 2000). In high market competition, the approach through sales force is a strategic choice for companies in obtaining the information related to the external environment (Sharma et al, 2009). This information is certainly very useful for companies to detect opportunities and threats that come (Thietart, 1981). Kotler (2011) defines sales force as all people who work in an organization whose job is to sell products and services directly and provide information related to ongoing business operations (Kotler \& Keller, 2011).

The sales force is considered as an important component of integrated marketing communication so that companies can achieve goals in the form of profits (Anca \& Moise, 2012). Getting a competitive position in business and winning a greater number of loyal customers is the main goal for the company. If the company is ambitious in selling orientation, the sales force will take a leading role in gaining competitive advantage in a market. The characteristic of a sales force is the sales contact process directly with consumers, serving and understanding consumers (Anca \& Moise, 2012). Although the role of the sales force is seen as a strategic key, the manager must understand which sales behaviour is capable of producing accurate information (Anderson \& Olover, 1987). however, the ability of a sales force in a company to be influenced by its knowledge, the higher the knowledge possessed, the faster the ability to capture the information needed by the company (Flatten et al, 2011). The sales force dimension was popularized by Churchill et al (2000) which included: skills, technical, marketing, and knowledge. This dimension illustrates that not all salespeople are able to contribute to collect the information.

Direct relationships, services provided, and receiving complaints from consumers are important tools of information resources. Therefore this information will be a strength for the company to provide products or services and be able to ahead its competitors. The importance of information makes sales not only serve sales but also takes on the role of espionage in their environment. Espionage in information seeking is referred to by McDowell (2009) as an intelligence activity. For some companies, sales may function as salespeople who are active in offering products, but the very high demands of competition require sales forces to switch from hard sales to smart sales (Langerak, 2001; Shervani, 1998; Kumar, 1994).

\section{Strategic Intelligence Activity}

The role of the sales force is acknowledged as the key to the success of a company in carrying out business activities. But without the information obtained, the company will be far behind its competitors, because the external information provided by the sales force will help the organization to provide products 
and services before the competition starts (Sheen, 2017). Especially for small and medium enterprises SMEs, if they are unable to obtain external information properly, it will certainly have an impact on the sustainability of the company's business (Dursi \& Freenhof, 2014). This explanation can be underlined that SME-based companies need information in order to survive in face of competition and be able to adapt business trends that change frequently (Sheen, 2017), or even when they find opportunities to diversify products, acquire and merge ( Keeny, 2009). Maccoby (2011) suggests for every manager when competing, managers should strive for the sales force to have a future review through searching for information around (Maccoby, 2011).

Strategic intelligence is a systematic information search through resources that are owned (McDowell, 2009). In history, intelligence activity is often used in military activities to find information related to enemy opponents or even used as a problem solver in an agency or institution (McDowell, 2009). however, studies have noted that intelligence activity has attracted much attention for managers to implement in understanding their competitors (Sheen, 2017). In this activity, each company must involve the resources it has, then processes it so that the results can be used to complete the needs in strategic planning and provide answers to the problems faced (McDowell, 2009).

Sheen (2017) states that intelligence activity is a means of searching information through intelligence possessed from what is known, integrated with new information and finally interpreted its meaning. The purpose of this activity is to fill the needs at the management level in achieving the assigned mission. In developing a strategy that is sustainable the need for information to give the contribution to the organization that can be flexible in adjusting the business to the current conditions. Maccoby (2001) mentions three processes, (1) Companies should be able to understand the current situation that might present threats or opportunities for the organization. (2) Conceptualizing future conditions by involving resources to implement it. (3) Develop alliances to obtain information. The model mentioned by Maccoby will lead to a conclusion that is as strategic planning (Natalia, 2013). But in the process, of course, it must be structured and systematic that demands data collection, receives relevant data at this time, analyzes, directs, implements and then reviews (McDowell, 2009)

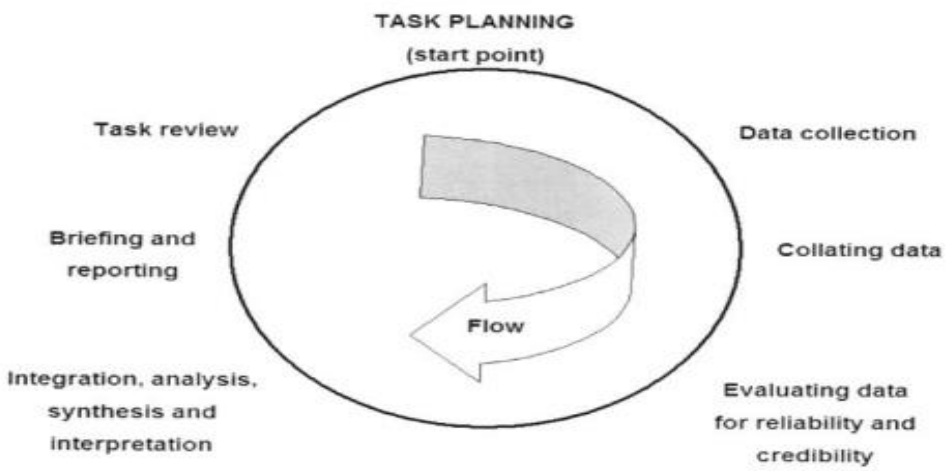

Figure 1 Task Planning SI (McDowell, 2009)

\section{Performance}

Performance is a measure for the level of success of a company in carrying out its objectives. Armstrong \& Baron (2007) suggested that performance is the result of work that has a strong relationship with strategic objectives. Management should create communication links to resources for the success of company goals. Performance as something that should be managed to get good results for the organization (Baron, 2007). in the context of SMEs usually performance focuses on each sales force activity to obtain greater sales (Alwi, 2008). Max \& Moullin (2007) stated that performance will provide information to assess the extent of excellence of an organization (Max \& Moullin, 2007). In measuring organizational performance, Booci (2004) divided into two things in measuring performance, the first measurement based on finance and second non-financial measurements. In formulating a strategy based on finances needed are only stakeholders, but in formulating non-financial strategies will involve innovation, motivation and services provided so that sales are increasing (Booci, 2004). 
Every organization may be measured by financial performance, where to be able to achieve this will also depend on the volume of sales made. However, sales volume cannot be achieved if the company cannot adjust the product to the trend that is in demand by consumers. Therefore to be able to compete, companies should accommodate as much information as possible about the product and its competitors (Palanisamy, 2005). Organizational flexibility is one of the measurements of company performance because if a company cannot adjust business with a growing trend, it will be far behind its competitors and this will have an impact on sales volume (Palanisamy, 2005). Activities to improve corporate control in order to have good performance, companies must be able to respond to information that exists in the environment. Ozer (2002) mentions the importance of flexibility in improving company performance given the changing business environment. So flexibility in business strategy is a requirement for an organization in achieving company sales growth (Bhandari, 2004) This is a concern for academics and practitioners as a source of competitive advantage (Dreyer \& Grounhoug, 2004).

\section{Research Methods}

This study used qualitative research and using a case study method, which did not use statistical generalization but rather with logical and replicative generalizations (Yin, 2011). To maintain validity and help to avoid researcher bias, this study used multiple cases with varying characteristics as research subjects (Creswell J. W., 2014).

The previous case was filtered using certain criteria as follows:

1. SMEs that carry out their business activities in the Beringharjo market, Yogyakarta.

2. SMEs have sales force in carrying out their business activities

3. SMEs have been running for at least 10 years

4. SMEs is the leader in its market share

The selected cases are 4 (four) SMEs (Beby Collection, Murti Collection, Sekarlathi Collection, dan Ponirah Collection).

This study used three methods of data collection are: interview, observation, and documentation methods to maintain data validity and reliability (Yin, 2014). The data validity test used data triangulation, member checking (informants/respondents will function as examiners throughout the analysis process and compare the researchers' interpretations with information from respondents to ascertain the correctness of the data), repeating observations at the research location, checking data with members of the researcher, involving respondents to examine interpretations and conclusions and clarifying research biases (Creswell J., 2014)

The case analysis process in this study uses three stages are: descriptive analysis (analyzing the results of research conducted on cases in general), within case analysis (analyzing all findings in each case), and crosscase analysis (analyzing and comparing findings between cases) (Edmonson, 2007).

Further analysis can be done by comparing the findings of each sample and then identifying patterns for generalization (Yin, 2009)

Figure 2: Case Study Analysis Process

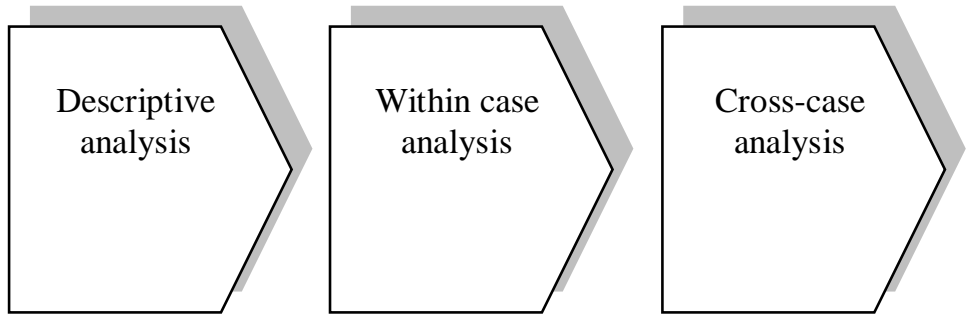

source: Eisendhart (1989)

This study was analyzed using the following model

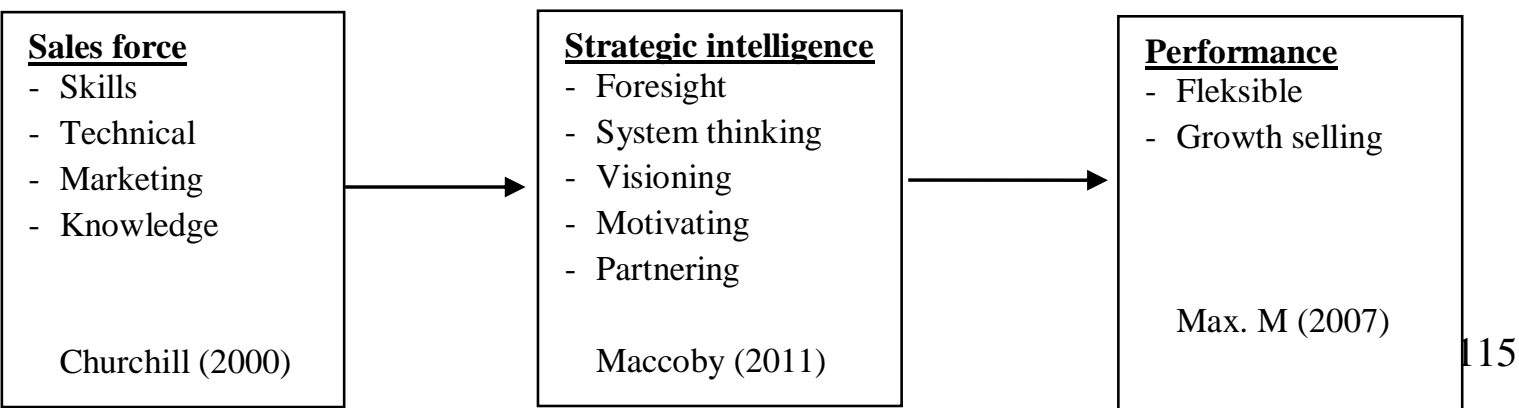


Variables and Measurements

Table 1. Variable and Measurements

\begin{tabular}{|c|c|c|}
\hline Variabel & Dimension & Measurement \\
\hline \multirow[t]{4}{*}{ Sales Force } & 1. Skills & $\begin{array}{l}\text { a. How far is the rapidity of } \\
\text { sales in providing products? }\end{array}$ \\
\hline & 2. Technical & $\begin{array}{l}\text { b. How far are sales skills in } \\
\text { providing products? } \\
\text { c. Is the timeliness in providing } \\
\text { products in line with } \\
\text { expectations? }\end{array}$ \\
\hline & 3. Marketing & $\begin{array}{l}\text { d. How is the sales ability in } \\
\text { selling products? } \\
\text { e. How is the sales ability to } \\
\text { negotiate when interacting with } \\
\text { consumers? }\end{array}$ \\
\hline & 4. Knowledge & $\begin{array}{l}\text { f. How is the sales ability to find } \\
\text { information about products and } \\
\text { competitors? } \\
\text { g. How far is the sales ability in } \\
\text { understanding the competitors } \\
\text { around them? }\end{array}$ \\
\hline \multirow[t]{6}{*}{ Staregic Intelligence } & 1. Foresight & $\begin{array}{l}\text { h. How far is the company's } \\
\text { knowledge of the market } \\
\text { mechanism (product distribution } \\
\text { to retail)? } \\
\text { i. How does the company set a } \\
\text { product price? } \\
\text { j. Does the company have a } \\
\text { permanent supplier in providing } \\
\text { products? } \\
\mathrm{k} \text {. What is the velocity of } \\
\text { product delivery when ordered? }\end{array}$ \\
\hline & $\begin{array}{l}\text { 2. System Thinking } \\
\text { (terkait produk) }\end{array}$ & $\begin{array}{l}\text { 1. How does the company } \\
\text { understanding the quality of the } \\
\text { products ordered? }\end{array}$ \\
\hline & & $\begin{array}{l}\mathrm{m} . \text { How far is the knowledge of } \\
\text { the brand of a product? }\end{array}$ \\
\hline & & $\begin{array}{l}\text { n. How does the company } \\
\text { understand consumer tastes? } \\
\text { o. Does the company have the } \\
\text { product supply? }\end{array}$ \\
\hline & 3. Visioning & $\begin{array}{l}\text { p. What is the view of the } \\
\text { company in understanding the } \\
\text { market and competitors? } \\
\text { q. Does the company have the } \\
\text { same strategy as competitors? }\end{array}$ \\
\hline & & $\begin{array}{l}\text { r. How does the company } \\
\text { establish relationships with }\end{array}$ \\
\hline
\end{tabular}




\section{Partnering}

5. Motivating

Performance
1. Fleksible

\section{customers?}

s. How good is the service provided to customers?

t. How does the company motivate their sales?

u. Does the company give trust to sales in managing retail?

v. Is the company able to adjust the growing business trend?

w. How does company understand the competitive market?

2. Growth Selling x. How is the company's strategy in increasing sales?

\section{Results And Discussion}

The company profiles are as follows:

Tables 2. Company Profile

\begin{tabular}{cccccc}
\hline SMEs & Established & Product & Market & Sales & Suplier \\
\hline Beby Collection & 1993 & $\begin{array}{c}\text { Bahan batik, } \\
\text { pakaian batik, } \\
\text { Mukena dll }\end{array}$ & Beringharjo & 6 & S Supplier \\
\hline Murti Collection & 2000 & $\begin{array}{c}\text { Bahan Batik, } \\
\text { pakaian batik, } \\
\text { Lurik }\end{array}$ & Beringharjo & 8 & 7 Supplier \\
\hline Sekarlathi & 1997 & $\begin{array}{c}\text { Produk kameja } \\
\text { batik, } \\
\text { Sellection }\end{array}$ & Beringharjo & 4 & 5 Supplier \\
\hline Ponirah Collection & 2001 & $\begin{array}{c}\text { Seragam } \\
\text { Batik }\end{array}$ & Beringharjo & 4 & 4 Supplier \\
\hline
\end{tabular}

The results and discussion in this study were carried out with descriptive and within case analysis to get a general description of the company. The next is cross case analysis to find patterns that appear in the case study in the field as follows:

\section{Sales force}

The importance of information encourages every company to be able to move its resources. The role of the sales force in a company is certainly very important for the operations of the business being run. This company has a number of 6-10 sales managed by managers. from these six sales, they have expertise that is different from one another. The findings obtained at the four companies related to the sales force and its dimensions (skills, technical, marketing and knowledge) appear in the following table:

\section{Company 1 (Beby Collection)}

\begin{tabular}{|c|c|c|c|}
\hline No & Dimension & Result analysis & Case findings from supporting literature \\
\hline 1 & Skills & Confirmed & $\begin{array}{l}\text { The sales force skills owned by this } \\
\text { company are quite good, but it would be } \\
\text { better if he was able to be a good and } \\
\text { enthusiastic listener so that when explaining } \\
\text { a product it would be very easy for } \\
\text { consumers to understand. As stated by } \\
\text { Kitchen ( } 2010 \text { ) that the skills possessed by } \\
\text { each sales are the ability to serve consumers } \\
\text { in interacting to fulfill needs. }\end{array}$ \\
\hline 2 & Technical & Confirmed & $\begin{array}{l}\text { Technical functions to facilitate managing a } \\
\text { product, starting from communication }\end{array}$ \\
\hline
\end{tabular}


between employees, providing products and packaging. Although the sales people at this company are mostly women, they have their own techniques in managing when the product comes to the selling stage

3 Marketing Confirmed

4 Knowledge $\quad$ Confirmed
The ability to negotiate and understand the wishes of consumers are said to be quite good regardless of the big and small sales.

The knowledge owned by sales in this company is very good and this can be seen by the rapid jumps in the field of logic such as the ability to look at the market situation (requests and offers), as well as listening to and evaluating complaints conveyed by the counselors.

\section{Company 2 (Murti Collection)}

\begin{tabular}{|c|c|c|c|}
\hline No & Dimension & Result analysis & Case findings from supporting literature \\
\hline 1 & Skills & Confirmed & $\begin{array}{l}\text { The sales force skills owned by this } \\
\text { company are quite good, this can be seen } \\
\text { from how to serve consumers and their } \\
\text { interactions. And this is in line with that } \\
\text { proposed by Weitz (1981) that sales skills } \\
\text { are the ability to salespeople themselves to } \\
\text { change their behaviour when interacting. }\end{array}$ \\
\hline 2 & Technical & Confirmed & $\begin{array}{l}\text { The technical owned by this company is } \\
\text { quite good, this can be seen when } \\
\text { salespeople are quick in providing products. }\end{array}$ \\
\hline 3 & Marketing & Confirmed & $\begin{array}{l}\text { The ability to sell and negotiate with } \\
\text { consumers is quite good. }\end{array}$ \\
\hline 4 & Knowledge & No Confirmed & $\begin{array}{l}\text { The knowledge that is owned by sales in this } \\
\text { company needs to be developed, given that } \\
\text { the understanding of the product is very } \\
\text { small. This can be overcome if sales are able } \\
\text { to become good listeners, look at the } \\
\text { situation and receive criticism from } \\
\text { consumers so that the concept of hard sales } \\
\text { becomes smart sales (Stanley, 1984) }\end{array}$ \\
\hline
\end{tabular}

\section{Company 3 (Sekarlathi Collection)}

\begin{tabular}{|c|c|c|c|}
\hline No & Dimension & Result analysis & Case findings from supporting literature \\
\hline 1 & Skills & Confirmed & $\begin{array}{l}\text { The sales force skills owned by this } \\
\text { company in serving consumers are quite } \\
\text { good, but understanding in a product needs } \\
\text { to be improved again }\end{array}$ \\
\hline 2 & Technical & Confirmed & $\begin{array}{l}\text { Technical includes ability in communication, } \\
\text { interpersonal skills when listening to } \\
\text { consumer demand and providing good } \\
\text { products. }\end{array}$ \\
\hline 3 & Marketing & Confirmed & $\begin{array}{l}\text { The ability to sell and negotiate and sell } \\
\text { quite good. }\end{array}$ \\
\hline 4 & Knowledge & Not Confirmed & $\begin{array}{l}\text { The knowledge that is owned by sales in this } \\
\text { company in making rapid jumps related to } \\
\text { the product is very slow, this is due to the } \\
\text { little variation in the products they have. }\end{array}$ \\
\hline
\end{tabular}


Company 4 (Ponirah Collection)

\begin{tabular}{|c|c|c|c|}
\hline No & Dimension & Result analysis & Case findings from supporting literature \\
\hline 1 & Skills & Confirmed & $\begin{array}{l}\text { The sales force skills that owned by this } \\
\text { company in serving consumers are quite } \\
\text { good }\end{array}$ \\
\hline 2 & Technical & Confirmed & $\begin{array}{l}\text { Technical includes ability in communication, } \\
\text { interpersonal skills when listening to } \\
\text { consumer toward request is quite good. }\end{array}$ \\
\hline 3 & Marketing & Confirmed & $\begin{array}{l}\text { The ability to sell sales to this company is } \\
\text { quite good. }\end{array}$ \\
\hline 4 & Knowledge & Confirmed & $\begin{array}{l}\text { The knowledge that is owned by sales in this } \\
\text { company in making rapid jumps related to } \\
\text { the product is very good. }\end{array}$ \\
\hline
\end{tabular}

\section{Strategic intelligence activities}

Strategic intelligence is an activity based on knowledge in collecting the information about a product and competitor before the business competition begins. The findings obtained on strategic intelligence and their dimensions (foresight, system thinking, visioning, motivating, and partering) appear in the following tables:

\section{Company 1 (Beby Collection)}

\begin{tabular}{|c|c|c|c|}
\hline No & Dimension & Result analysis & Case findings from supporting literature \\
\hline 1 & Foresight & Confirmed & $\begin{array}{l}\text { This company has an orientation to detect } \\
\text { business trends in the future. As Becker } \\
\text { (2001) states that foresight in strategic } \\
\text { intelligence, generally functions to describe } \\
\text { the business situation obtained from the } \\
\text { information. }\end{array}$ \\
\hline 2 & System thinking & Confirmed & $\begin{array}{l}\text { Understanding of interactions that are owned } \\
\text { is quite good in this case so that } \\
\text { organizational goals can be realized. }\end{array}$ \\
\hline 3 & Visioning & Confirmed & $\begin{array}{l}\text { The view to detect business trends owned by } \\
\text { this company is quite good. The information } \\
\text { obtained is then communicated to resources } \\
\text { and involves everyone in the company in } \\
\text { implementing it. }\end{array}$ \\
\hline 4 & Partnering & Confirmed & $\begin{array}{l}\text { This company has a strategic relationship } \\
\text { with both its customers and its partners who } \\
\text { are suppliers. Maccoby (2008) companies } \\
\text { must establish good relationships with their } \\
\text { partners so that they can survive. }\end{array}$ \\
\hline 5 & Motivating & Confirmed & $\begin{array}{l}\text { The owner of this company often motivates } \\
\text { employees to realize their goals together. } \\
\text { This motivation is sometimes given in the } \\
\text { form of financial or non-financial bonuses }\end{array}$ \\
\hline
\end{tabular}

\section{Company 2 (Murti Collection)}

\begin{tabular}{llll}
\hline No & Dimension & Result analysis & Case findings from supporting literature \\
\hline 1 & Foresight & Not Confirmed & $\begin{array}{l}\text { The ability to review business trends and } \\
\text { market mechanisms needs to be improved, as } \\
\text { well as increasing suppliers. This will be } \\
\end{array}$ \\
& & $\begin{array}{l}\text { very helpful when the company receives } \\
\text { many orders. }\end{array}$ \\
\hline 2 & System thinking & Not Confirmed & $\begin{array}{l}\text { The understanding of a product is quite } \\
\text { good, but the understanding Market } \\
\end{array}$ \\
& & $\begin{array}{l}\text { mechanism, market situation and supplier } \\
\text { need to be improved. }\end{array}$ \\
& &
\end{tabular}




\begin{tabular}{|c|c|c|c|}
\hline 3 & Visioning & Not Confirmed & $\begin{array}{l}\text { Understanding of the business situation still } \\
\text { needs to be improved, because this company } \\
\text { is still dependent on the surrounding shops. }\end{array}$ \\
\hline 4 & Partnering & Confirmed & $\begin{array}{l}\text { This company has a good strategic } \\
\text { relationship with its partners, when there is } \\
\text { an order In large quantities, he simply } \\
\text { borrows goods from his partners, but this } \\
\text { results in a delay in time so that old } \\
\text { customers wait. }\end{array}$ \\
\hline 5 & Motivating & Confirmed & $\begin{array}{l}\text { The motivation given by the owner to the } \\
\text { salespeople is still felt lacking, this can be } \\
\text { seen in the behavior of salespeople who are } \\
\text { not dexterous/skillful. }\end{array}$ \\
\hline
\end{tabular}

\begin{tabular}{|c|c|c|c|}
\hline No & Dimension & Result analysis & Case findings from supporting literature \\
\hline 1 & Foresight & Not Confirmed & $\begin{array}{l}\text { The ability to review business trends needs } \\
\text { to be improved, as well as increase } \\
\text { information regarding products that are the } \\
\text { current trend. }\end{array}$ \\
\hline 2 & System thinking & Not Confirmed & $\begin{array}{l}\text { Understanding of a product needs to } \\
\text { multiply given the different needs of } \\
\text { consumers. }\end{array}$ \\
\hline 3 & Visioning & Not Confirmed & $\begin{array}{l}\text { Understanding of external situations, } \\
\text { especially related to products, still needs to } \\
\text { be improved, because this company is still } \\
\text { involved in one type of product. }\end{array}$ \\
\hline 4 & Partnering & Confirmed & $\begin{array}{l}\text { This company has a strategic relationship } \\
\text { with its partners and customers }\end{array}$ \\
\hline 5 & Motivating & Not Confirmed & $\begin{array}{l}\text { The motivation is given by the owner to the } \\
\text { salespeople was still felt lacking. }\end{array}$ \\
\hline
\end{tabular}

\section{Company 4 (Ponirah collection)}

\begin{tabular}{llll}
\hline No & Dimension & Result analysis & Case findings from supporting literature \\
\hline 1 & Foresight & Confirmed & $\begin{array}{l}\text { Ability to review business trends, as well as } \\
\text { information related to products whose } \\
\text { current trends are quite good. }\end{array}$ \\
\hline 2 & System thinking & Confirmed & $\begin{array}{l}\text { In the understanding of a product that } \\
\text { includes quality, consumer tastes are quite } \\
\text { good }\end{array}$ \\
\hline 3 & Visioning & Confirmed & $\begin{array}{l}\text { Understanding of the external situation of } \\
\text { the business is quite good, because this } \\
\text { company is still active in seeking } \\
\text { information }\end{array}$ \\
\hline 4 & Partnering & $\begin{array}{l}\text { This company has a good relationship with } \\
\text { its partners and customers }\end{array}$ \\
\hline 5 & Motivating & Confirmed & $\begin{array}{l}\text { The motivation given by the owner to the } \\
\text { salespeople was quite good }\end{array}$ \\
\hline
\end{tabular}

\section{Performance}

Performance is the ability of an organization to achieve its stated goals and become a measurement and success of the company. In looking for excellence, performance is usually focused on every resource that is owned. The ability of an organization will be seen when it is able to adjust to changes to products that are of interest to consumers and able to respond to information. The results of the findings on four companies related to performance and their dimensions (flexible and increased sales) appear in the following tables: 


\section{Company 1 (Beby Collection)}

\begin{tabular}{llll}
\hline No & Dimension & Result analysis & Case findings from supporting literature \\
\hline 1 & flexible & Confirmed & $\begin{array}{l}\text { Flexible in an organization is the ability to } \\
\text { adjust the business situation, it is able to } \\
\text { adapt to the environment (Palanisamy, } \\
\end{array}$ \\
& & $\begin{array}{l}\text { 2005). Through the response of information } \\
\text { obtained from sales, the flexibility of this } \\
\text { company is quite good. }\end{array}$ \\
\hline 2 & Improvement sales & Confirmed & $\begin{array}{l}\text { The success of the strategy in a business will } \\
\text { have an impact on sales growth (Bh \& ari } \\
\end{array}$ \\
& $\begin{array}{l}\text { 2004). This company is quite good at } \\
\text { formulating strategies by doing partners with } \\
\text { its suppliers, thus impacting sales growth. }\end{array}$ \\
\hline
\end{tabular}

Company 2 (Murti Collection)

\begin{tabular}{llll}
\hline No & Dimension & Result analysis & Case findings from supporting literature \\
\hline 1 & Flexible & Not Confirmed & $\begin{array}{l}\text { This company is still lack of ability to adjust } \\
\text { the business or trend of a product. This is } \\
\text { because it is still dependent on other stores, } \\
\text { so the trend follows other shops }\end{array}$ \\
\hline 2 & Improvement sales & Confirmed & $\begin{array}{l}\text { Even though it is said that the company has } \\
\text { restrictiveness in terms of products, Bu } \\
\text { Murti has a strategy to expand his shop as } \\
\text { well as a reasonably good pricing strategy. }\end{array}$ \\
\hline
\end{tabular}

Company 3 (Sekarlathi collection)

\begin{tabular}{llll}
\hline No & Dimension & Result analysis & Case findings from supporting literature \\
\hline 1 & Flexible & Not Confirmed & $\begin{array}{l}\text { This company is still considered to be unable } \\
\text { to adjust to the business situation. }\end{array}$ \\
\hline 2 & Improvement sales & Not Confirmed & $\begin{array}{l}\text { This company is fairly slow to increase its } \\
\text { sales. It can be seen from the products sold } \\
\text { and limited to only a few items so that } \\
\text { consumers prefer to choose stores that are } \\
\text { considered to be many variants of items. }\end{array}$ \\
\hline
\end{tabular}

Company 4 (Ponirah collection)

\begin{tabular}{llll}
\hline No & Dimension & Result analysis & Case findings from supporting literature \\
\hline 1 & Flexible & Confirmed & $\begin{array}{l}\text { It is quite good at adapting to the current } \\
\text { business situation }\end{array}$ \\
\hline 2 & Improvement sales & Confirmed & $\begin{array}{l}\text { This company is quite slow in increasing } \\
\text { sales because it is not brave to expand its } \\
\text { business network and only focus on one own } \\
\text { store. }\end{array}$ \\
\hline
\end{tabular}

Based on the good experience of the owner, the information obtained through the company's sales role is very different, there are who are able to adapt to the growing business trends and some who are slow to respond to information. Information is related to the sales given to the owner includes products that are in demand by consumers where this information is predicted to be trending in the future. In this case, the four companies also have good relations with their partners.

After doing the descriptive and within-case analysis. The researcher concludes that the case study that will be seen in the next table to ensure that the findings are appropriate and confirmed by the findings will be marked $(\bigvee \sqrt{ } \bigvee)$ for the strongest findings, $(\sqrt{ })$ for moderate findings, and $(\sqrt{ })$ for weakest findings which refers to the results of the within-case analysis. By conducting within-case analysis researchers will 
explore the patterns that arise based on case studies in the field where these results will be seen in the following table:

Table 3. Within-Case Analysis

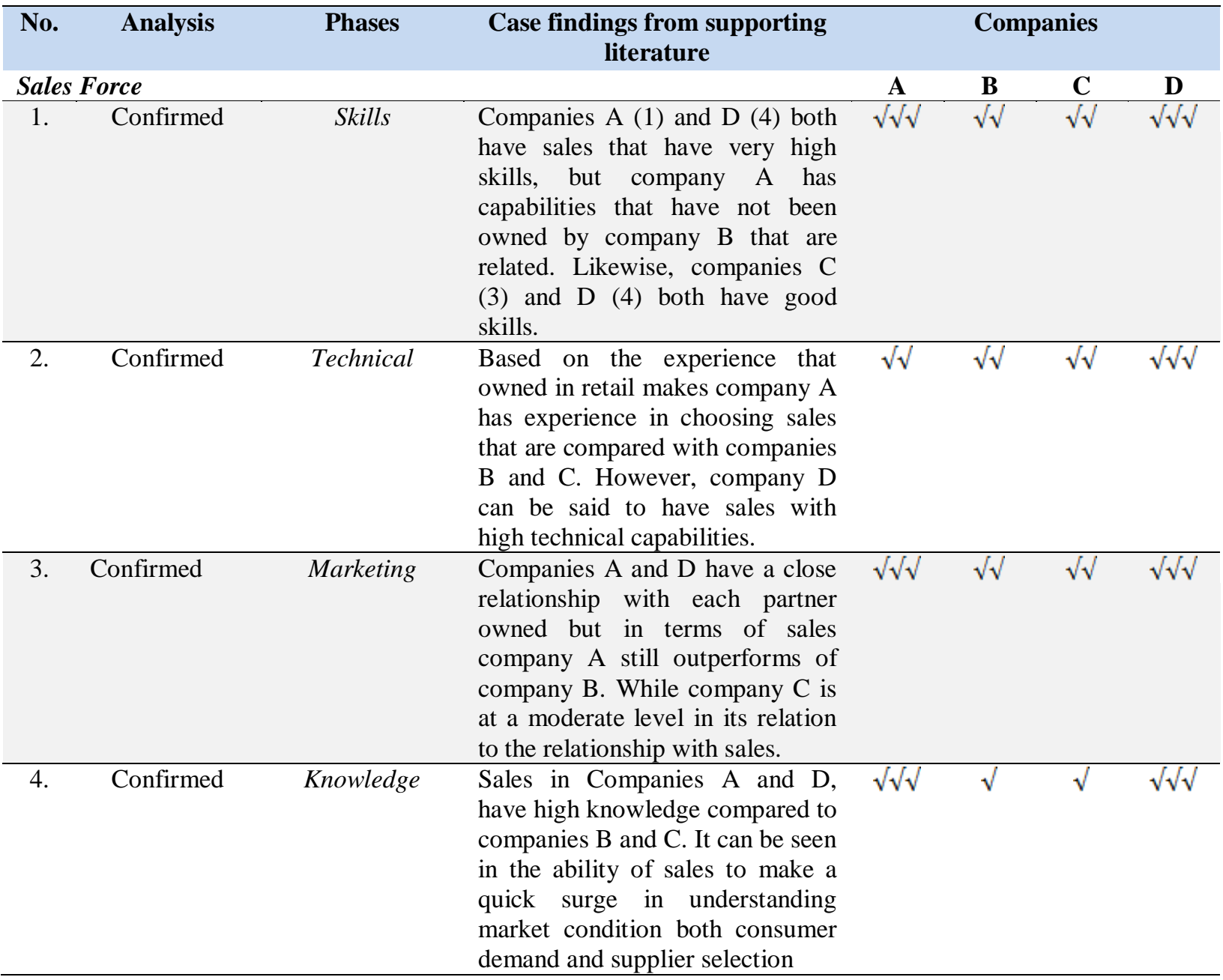

Skills sales owned by Beby collection (1) and Ponirah companies (4) are the highest compared to Murti collection and Sekarlathi companies ( $2 \& 3)$. It is because sales in both companies have enough experience in interacting with consumers and understanding the market environment so that the capabilities of the company $(1 \& 4)$ are more outperform. As for technical among the four companies, Ponirah collection (4) is higher, considering their good skill and insight. Marketing among the four companies is very good, but when viewed from the number of sales, the Beby collection is higher, it is because the company always provides product stock, as well as knowledge, sales in both companies always rise in understanding every consumer demand.

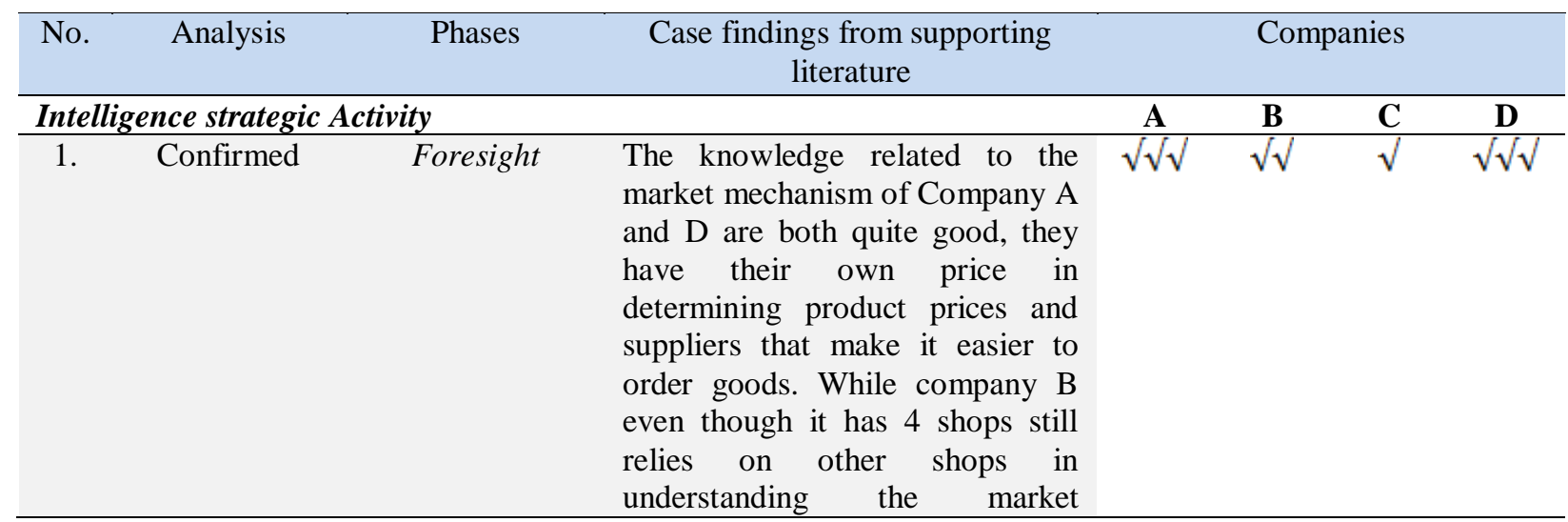


situation. While store $\mathrm{C}$ is still lacking understanding the market situation.

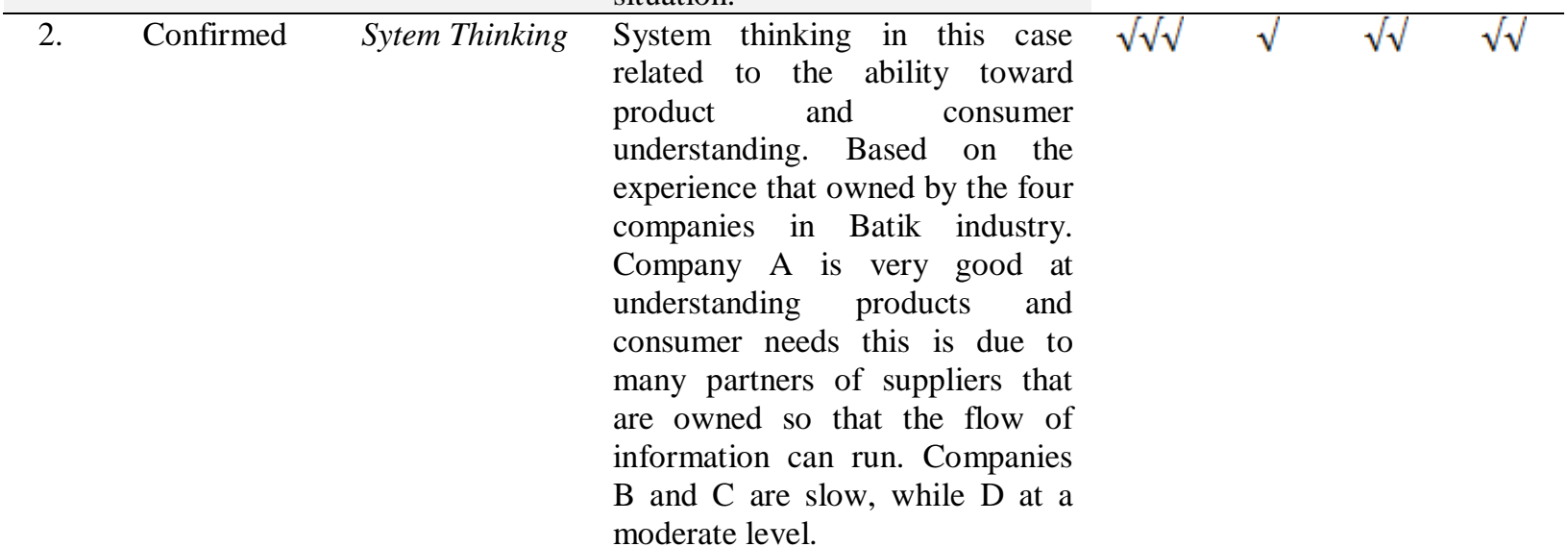

\begin{tabular}{|c|c|c|c|c|c|c|c|}
\hline & Confirmed & Visioning & $\begin{array}{l}\text { Through the information provided } \\
\text { by the sales force, companies A } \\
\text { and D are very good at reviewing } \\
\text { business situations, compared to } \\
\text { B and C. }\end{array}$ & $\sqrt{\sqrt{ }}$ & $\sqrt{ }$ & $\sqrt{ }$ & $\sqrt{\sqrt{ }}$ \\
\hline 4. & Confirmed & Partnering & $\begin{array}{l}\text { Companies B and C are } \\
\text { companies that partner with } \\
\text { companies that don't compete so } \\
\text { that they are at a moderate level. } \\
\text { While companies A and B have } \\
\text { partners with companies that } \\
\text { compete. All companies have the } \\
\text { same ability to deal with } \\
\text { consumers, but company A } \\
\text { outperforms other companies. } \\
\text { This is evidenced by the number } \\
\text { of customers who are loyal. }\end{array}$ & $\sqrt{\sqrt{ }}$ & $\sqrt{\sqrt{ }}$ & $\sqrt{\sqrt{ }}$ & $\sqrt{\sqrt{ }}$ \\
\hline 5 & Confirmed & Motivating & $\begin{array}{l}\text { The three companies } \mathrm{A}, \mathrm{B} \text { and } \mathrm{D} \\
\text { provide the same motivation to } \\
\text { the sales owned, but in terms of } \\
\text { giving trust to the sales } \\
\text { differently. If company } \mathrm{A}, \mathrm{B} \text { and } \\
\mathrm{D} \text { give trust to sales to manage } \\
\text { their shop, it is different from the } \\
\text { case with company C that does } \\
\text { not give trust to sales. }\end{array}$ & $\sqrt{\sqrt{ }}$ & $\sqrt{\sqrt{ }} \sqrt{ }$ & $\sqrt{ }$ & $\sqrt{\sqrt{ }}$ \\
\hline
\end{tabular}

Every organization is certainly not detached from its main goal of earning profits, increasing sales and being able to survive in the face of competition. In understanding the business environment of each company will certainly be different in mindset. It could be seen in the table above, Beby collection (1) and Ponirah collection (4) have a good understanding in reviewing a trend requested by the consumer, while Murti collection (2) is at a moderate level while company 3 is still left far behind. System thinking at the Beby collection company is superior to other companies. The partnering carried out in each company is very different, if companies 2 (Murti) and 3 (sekarlathi) they are partnering with companies that are not competitive, other than companies 1 (Beby collection) and 4 (Ponirah collection) they partnering with companies that compete one another. Finally, regarding motivation, all companies give encouragement to their sales by providing incentives if their sales exceed the target. However, the flexibility in managing the store, company 2 (Murti collection) and 3 (Sekarlathi collection) give limitation so that this prevents salespeople from making transactions. It is different from company 1 (Beby Collection) and 4 (Ponirah) which provide flexibility and trust in sales as long as they are able to increase sales and this became a strategic effort given by the two companies. 


\begin{tabular}{|c|c|c|c|c|c|c|c|}
\hline No. & Analysis & Phases & Case findings from supporting & & & & \\
\hline Perfo & ance & & & A & B & $\mathbf{C}$ & D \\
\hline 1. & Confirmed & Flexible & $\begin{array}{l}\text { The ability to adjust a business } \\
\text { that is owned by Company A is } \\
\text { very good, this is because the } \\
\text { flow of information received from } \\
\text { suppliers who are becoming their } \\
\text { partners is running well. } \\
\text { Company B, although it has four } \\
\text { stores assisted by their employees } \\
\text { is still lacking adjusting their } \\
\text { products, this is due to the desire } \\
\text { of owners who are reluctant to } \\
\text { move from their products, as well } \\
\text { as C companies that are slow to } \\
\text { respond due to information and } \\
\text { capital constraints. While } \\
\text { company D in adjusting products } \\
\text { with a fairly good trend. }\end{array}$ & $\sqrt{ } \sqrt{ }$ & $\sqrt{ }$ & $\sqrt{ }$ & $\sqrt{ } \sqrt{ } \sqrt{ }$ \\
\hline 2 & Confirmed & $\begin{array}{l}\text { Improvement } \\
\text { sales }\end{array}$ & $\begin{array}{l}\text { Company A outperforms other } \\
\text { companies because it is proved in } \\
\text { the increasing sales volume. }\end{array}$ & $\sqrt{\sqrt{ }}$ & $\sqrt{\sqrt{ }}$ & $\sqrt{ }$ & $\sqrt{\sqrt{ }}$ \\
\hline
\end{tabular}

The information provided by the sales force through strategic intelligence will lead to the organization to take action. Company 1 (Beby collection) and 4 (ponirah collection) with their capabilities and the flow of information from sales and partners outperforming the other two companies in terms of products. Whereas the company 2 (murti collection) and 3 (sekarlathi collection) the love of batik motifs favoured by the owner, it makes difficult to be able to adjust to the interests of consumers, and also the information flow is relatively lacking. While company 3 (Sekarlathi), although it has been established for a long time and has four employees, it is still unable to adjust the product due to limited capital, but it has alternatives to overcome its weaknesses depending on company 1 (Beby collection). As for the increase of sales which is seen in the opening of branches. currently, company 1 (Beby collection) is superior to other companies. Although the effect of the sales force is recognized as the key to the success of the organization, it will be far better if the company is able to adopt strategic intelligence as a support to improve performance.

Table 4. The Findings in Cross-case analysis

\begin{tabular}{ccccc} 
Components & Beby Collection & Batik Bu & Sekarlathi & Ponirah Collection \\
& (A) & Murti & Collection & (D) \\
& (B) & (C) & \\
\hline
\end{tabular}

\section{Sales Force}

\begin{tabular}{ccccc}
\hline Skills & Very high & Medium & Medium & Very high \\
\hline Technical & Medium & Medium & Medium & Very high \\
\hline Marketing & Very high & Medium & Medium & Very high \\
\hline Knowledge & Very high & Low & Low & Very high
\end{tabular}

Intelligence Strategic Activities

\begin{tabular}{ccccc}
\hline Foresight & Very high & Medium & Low & Very high \\
\hline System Thinking & Very high & Medium & Low & Medium \\
\hline Visioning & Very high & Very high & Very high & Very high \\
\hline Partnering & Very high & Medium & Medium & medium \\
\hline Motivating & Very high & Very high & Low & Very high
\end{tabular}




\begin{tabular}{cllll}
\hline Flexible & Very high & Medium & Medium & Very high \\
\hline Improvement sales & Very high & Medium & Medium & Medium
\end{tabular}

\section{Conclusion}

The findings in the field as a whole the company was able to manage the sales force well, but the contribution given by sales in providing information was very dependent on the sales character itself. Likewise the application of intelligence strategic. From the facts was found in the field, researchers obtained several conclusions regarding the process of managing sales force (skills, technical, marketing, knowledge) and strategic intelligence. Company 1 (beby collection) could outperform its competitors, namely company 2 (murti collection), 3 (sekarlathi collection), and 4 (ponirah collection). Companies that have not implemented strategic intelligence which include (foresight, system thinking, visioning, partnering, motivating) it is because the capacity and capability of the company's ability is still lacking. Companies that adopted strategic intelligence in carrying out their business operations would outperform their competitors because the access to information was so good so that it would have an impact on company performance where companies would be able to adjust business trends before the competition begins. If being noticed more specifically, the limitations of this study situated in the selected cases in the same field of SMEs and their location is limited to certain areas. Suggestions for further development, given the rapidly changing market trend, it is necessary to consider network performance variables (network performance) that could improve business performance and help companies to fulfil future information needs.

\section{References}

Ahmad S.Z, Basir M. SAH, \& Kitchen P.J, (2010). The Relationship between Sales Skills \& Salesperson Performance, \& the Impact of Organizational Comitment as a Moderator: An Empirical Study in a Malaysian Telecummunications Company. Journal of Economics \& Management, 4(No.2), pp.181221

Anshof. H, (1975). Managing Strategic Surprise by Response to Weak Signals. California Management Review. Winter/ No 2.

Adsiansyah \& Afif. A.Z, (2015). Organizational Culture, Absortive Capacity, Innovation Performance \& Competitive Advantadge: An Integrated Assessment In Indonesian Banking Industry. The South East Asian Journal Of Management Seam. Vol 9. No 1.

Auh. \& A. Uslu., (2013). Costumer Knowledge Creation Capability \& Performance In Sales Teams. Springer, 41, pp.19-39.

Adam. R, James \& Zulis, \& Raj.A, (2014). Competitive Intelligence Collection \& Use By Sales \& Service Representatives: How Managers Recognition. Journal Of The Academy Of Marketing Science. 43:357374.

Anderson. E, \& Oliver. L, (1987). Behavior \& Outcome Based Sales Control Systems: Evidence \& Consequences Of Pure From \& Hyberd Governance. Journal Personal Selling \& Sales Management. Jstor. Vol 15. No 4.

Andersen. J, (2012). "Protective Capacity \& Absorptive Capacity", The Learning Organization, Vol. 19 Iss 5 Pp. $440-452$

Benjamin, W.A, (1979). Management Of Business Information. Industrial Marketing Management. 8, 51-56.

Babakus E, Cravens D, \& Grant K, Ingram T, (1996). Investigating The Relationship Among Sales, Management Control, Sales Teorriority Design, Salesperson Performance, \& Sales Organization Effectiveness. International Journal Of Research In Marketing. 13: 345-363.

Behrman D, William, \& Perreault, (1982). Measuring The Performance Of Industrial Salesperson. Journal Of Business Research. 10 (3), pp. 355-357.

Cruceru. A \& Moise. D , (2012). The Characteristics Of Sales Forces In Relation With Marketing Activies Carried Out By The Romanian Companies. Procedia-Sosial \& Behavioral Sciences, 62, pp.198-202.

Creswell, J.., (2014). Research design: qualitative, quantitative, quantitative \& mixed methods approach 4th ed., Tous\& Oaks, CA: Sage.

Coff. R \& Kryscynski, (2011). Drilling For Micro-Foundations Of Human Capital Based Competitive Advantages. Drillin For Micro-Foundations 2.

Cravens, Nigel F, \& Neil A Morgan, (1996) Salesforce Performance \& Behavior-Based Management Processes In Business-To-Business Sales Organizations. Europan Journal Of Marketing. Vol. 32 
No.1/2, Pp. 79-100.

Cohen, \& Daniel. A, (1990). Absortive Capacity: A New Perspective On Learning \& Innovation. Sage Publications. Vol. 35, No. 1, Pp. 128-152.

Craig. S, \& Babette E. Bensoussan, (2007). Business \& Competitive Analysis. Ft Press, vol. 1. pages 491.

Churchill. Gilbert. A, 2000. Salesforce Management. Paperback-International Edition.

Clel\&. I, \& King. W.R, (1975). Management: A Systems Approach. Mcgraw-Hill.

Dauglas M. Lambert, Howard Marmorstein, \& Arun Sharma., (1990). Industrial Salespeople As A Source Of Market Information. Industrial Marketing Management. 19, pp. 141-148 .

Eliashberg \& G.L Lilien, (1993). H\&books In Or Ms, Vol 5. Elsevier Science Publisher.

Elliot Maltz, \& Ajay K. Kohli, (1996). Marketing Intelligence Dissemination Across Functional Boundaries. Journal Of Marketing Research. vol, 33, no.1, pp. 47-61.

Eisenhardt, K.M., (1989). Building theory from case study research. Academy of Management Review, 14(4), pp.532-550.

Flaten C, Andreas. E, \& Shaker A, (2011). A Measure Of Absortive Capacity: Scale Development \& Validation. Europan Management Journal. 29,98, 1-16.

Gayer R, \& Jackson T, (2004). Suply Loops \& Their Constraints: The Industrial Ecology Of Recyling \& Reuse. California Management Review, 46 (2), 55-73.

Goran Roos, \& Johan Roos, (1997). Measuring Your Company's Intellectual Performance. Elsevier Science. vol. 30, no.3, pp. 413-426.

Goran Roos \& Johan Roos.,(1997). Measuring Your Company's Intellectual Performance. Elsevier Science. vol. 30, no. 3, pp 413-426

Hamid. M \& Khamseh D, (2008). Knowledge Transfer In Alliances: Determinant Factors. Journal Of Knowledge Management, vol. 122 iss 1, pp. 37-50.

Ingram. T. N, (2005). New Directions In Sales Leadership Research. Journal Of Personal Selling \& Sales Management. 25 (2). pp. 137-154.

Javalgi, Thomas W. Whipple, \& Amit K. Ghosh., (2005). Market Orientation, Strategic Flexibility, \& Performance: Implications For Service Providers. Journal Of Services Marketing. 19 (4), pp.212-221.

Jim \&ersen., (2012). Protective Capacity \& Absortive Capacity: Managing The Balance Between Retention \& Creation Of Knowledge-Based Resources. The Learning Organization. vol, 50 No, 5. pp. 43-57.

Jon L. Pierce \&\&re L. Delbecq.., (1997). Organization Structure, Individual Attitude \& Innovation. The Academy Of Management Review, Vol. 2. No 1, Pp 27-37.

Kedia, B.L. \& Bhagat, R.S., (1988). Cultural constrains on transfer of technology accross nation: implication for research in international \& comparative management. Academy of Management Review, 13(4), pp.559-571.

Kitchen P.J, Basir M Sah, \& Ahmad, (2010). The Relationship Between Sales Skills \& Salesperson Performance, \& The Impact Of Organizational Comitment As A Moderator: An Empirical Study In A Malaysian Telecummunications Company. Journal Of Economics \& Management, 4(No.2), pp.181221.

Loch K. Johnson., (2011). Preface To A Theory Of Intelligence strategic. International Journal Of Intelligence \& Counterintelligence, 16 (4), pp.638-663.

Mark B. V\&enbosch \& Charles B. Weinberg., (1993). Sales Force Operations. H\&books, vol. 5.

Maccoby., (2011). The Humanside: Successful Leaders Employ Intelligence strategic. Research Technology Management, 44(3), pp.58-60.

Margaret P, Giada Di Stefano, \& Gienmario Verona., (2013). The Elephant In The Room Of Dynamic Capabilities: Bringin Two Diverging Conversations Together. Strategic Management Journal. Wiley. 34, pp.1389-1410.

Max Moulin, (2007). Performance Measurement Definitions: Linking Performance Measurement \& Organisational Exellence. Emerald Publising. vol. 20 (3). pp. 181-183.

March, J.G. \& Simon, H.A., (1958). Organization, New York: Wiley.

Maxwell, J.A., (2005). Qualitative research design: An interactive approach, London: Sage Publication Inc.

Miles, M.B. \& Huberman, A.M., (1994). Qualitative data analysis: an exp\&ed soucebook, London: Sage Publication Inc.

Nicholas C, \& Lie, (2000). A Method For Determining The Causes Of Salesperson Turnover. Journal of Personal Selling \& Sales Management. vol. 3, issue 1. pp 26-35.

Natalia Ana Strain., (2013). Intelligence strategic Role In The Management Of Organizations. The Usv Annals Of Economics \& Public Administration. Vol. 13, Issue 2 (8).

Nikala Lane., (2009). Searching For Strategy In Sales. Journal Of Strategic Marketing, Vol. 17, No 3, Pp 191-197.

Paolo G, (2010). Sales Force Activities \& Customer Trust. Journal Of Marketing Management, 18:7-8, Pp 749-778.

Piotr Kwiatek, Grzegorz Leszczynski, \& Marek Zielinski., (2011). Salespeople As A Source Of Information 
For Business Buyers. Researchgate, Conference Paper.

Rusell Coff \& David Kryscynski.., (2011). Drilling For Micro-Foundations Of Human Capital Based Competitive Advantage. Journal Of Management, 37(5), pp.1429-1443.

Raymond E. Miles \& Charles C. Snow., (2003). Organizational Strategy, Structure, \& Proses. Mcgraw-Hill Series In Management.

Sheen S. Levine, Mark Bernard, \& Rosemarie Nagel., (2017). Intelligence strategic: The Cognitive Capability To Anticipate Competitor Behavior. Strategic Management. 38, pp 2390-2423.

Stanley F. Slater \& Eric M. Olson., (2000). Strategic Type \& Performance: The Influence Of Sales Force Management. Strategic Management Journal, 21, pp.813-829.

Stake, R.., 1995. The art of case study, Tous\& Oaks, CA: Sage.

Sundara Rajan., (2015). Interpersonal Skills For Sales Force Effectiveness- A Survey On Indian Pharmaceutical Industry. International Journal Of Economic \& Management Sciences. vol. 4. issue 5.

Thietart \& R. Vivas., (1981). Intelligence strategic Activity: The Management Of Sales Force A Source Of Strategic Information. Strategic Management Journal. vol. 2. pp 15-25.

Voss, C., Tsikrlktsii, N. \& Frochlich, M., (2002). Case research in operations management. Operation \& Production Management, 22(2), pp.195-219.

Verona., (2013). The Elephant In The Room of Dynamic Capabilities: Bringin Two Diverging Conversations Together. Strategic Management Journal. Wiley. 34, pp.1389-1410.

Willem J. Verbeke, Frank D. Belschak, Arnold B Bakker, \& Bart Dietz.,(2008). When Intelligence Is (Dys) Functional For Achieving Sales Performance. Journal Of Marketing. American Marketing Association. vol. 72. pp 44-57.

Yin, R.K., (2009). Case study research : design \& methods 4th ed., London: Sage Publication.

Yin, R.K., (2014). Case Study Research: Design \& Methods 5th ed., Thous\& Oaks, CA: Sage Publication.

Yin, R.K., (2011). Qualitative research from start to finish, New York: The Gulford Press.

Zachary R. Hall, Ryan R, Niladri Syam, \& Jeffrey P. Boichuk., (2017). Generating \& Sharing Of Market Intelligence In Sales Teams: An Economic Social Network Perspective. Journal Of Personal Selling \& Sales Management, 37(4), pp 298-312.

Zahra, S.A. \& Goerge, G., (2002). Absorptive Capacity: A Review, Reconceptualization, \& Extension. Academy of Management Review, 27(2), pp.185-203.

Zerwas, D., (2014). Organizational Culture \& Absorptive Capacity: The Meaning for SMEs, Koblenz-L\&au, Germany: Springer Gabler. 